\title{
CEO Duality Leadership And Firm Risk-Taking Propensity
}

Kong-Hee Kim, (E-mail: kkim@stcloudstate.edu), St. Cloud State University Robert Buchanan, (E-mail: rbuchanan@ucok.edu), University of Central Oklahoma

\begin{abstract}
Based on a sample of 290 large U.S. corporations, we find that dual positioning on both CEO and board chairperson positions at the corporate top leads to reduced firm risk-taking propensity, serving managerial risk minimization preferences. We also find empirical evidence that traditionally emphasized control mechanisms of board independence and managerial ownership are ineffective in controlling managerial behavior when CEO duality leadership exists. Additionally, the power balance obtained from concentrated shareholder ownership in the firm has significant impact on controlling managerial behavior regarding firm risk taking. The findings of this research contribute to reducing the controversy surrounding CEO duality leadership by furnishing empirical evidence of how CEO duality leadership in corporate governance structure affects managerial behavior in corporate strategic management.
\end{abstract}

Keywords: CEO Duality, Firm Risk-taking Propensity, Ownership Concentration

\section{INTRODUCTION}

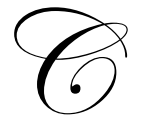

EO duality occurs when the same person occupies both the CEO and board chairperson positions in a corporation (Rechner \& Dalton, 1991). On the other hand, if different individuals serve in these two pivotal positions, the firm can be said to adopt a separate leadership structure. The fundamental question surrounding CEO duality leadership is whether the chairperson's position should be filled by the CEO or by a different person (Daily \& Dalton, 1997). A central concern has been whether one person's positioning at the corporate pivotal positions of CEO and board chairperson weakens corporate governance effectiveness, leading to managerial opportunism and resulting in reduced firm performance (Brickley, Coles, \& Jarrell, 1997; Finkelstein \& D'Aveni, 1994). From the agency theory perspective, having one individual in charge of both management implementation and control is not consistent with the concept of checks and balance. However, from an organization theory perspective, CEO duality may enhance organizational efficiency in corporate leadership (Boyd, 1995).

Most theoretical arguments against the practice of CEO duality leadership have centered on the issue of power concentration on dual CEO (Brockmann, Hoffman, Dawley, \& Fornaciari, 2004; Daily \& Dalton, 1997). Duality has been described as a concentration of power on the dual CEO, enabling dual CEOs to dominate the board, reducing board effectiveness in monitoring and controlling the management (Fama \& Jensen, 1983; Westphal $\&$ Zajac, 1998). CEO duality leadership implies a heightened formal authority and greater informal power for the one individual who occupies two positions, both as CEO in management implementation and board chairperson in management control (Harrison, Torres, \& Kukalis, 1988). In addition to formal hierarchical power on the executive team derived from the position as CEO, by virtue of their position as chairperson of the board, dual CEOs can exert substantial influence on the board by controlling the information flows to the board and through intervening in the process of new director appointment (Dayton, 1984).

Researches in the past on organizational outcomes associated with CEO duality have generally focused on the performance dimension, and have provided divergent empirical prescriptions regarding the performance consequences of CEO duality leadership (Boyd, 1995; Dalton, Daily, Ellstrand, \& Johnson, 1998; see Table 1 below for summary). While some studies find a negative effect of duality leadership on corporate performance (e.g., Daily 
\& Dalton, 1994; Rechner \& Dalton, 1991), others have observed positive effects (e.g., Donaldson \& Davis, 1991), and still others have found no significant relationship between CEO duality and firm performance (Chaganti, Mahajan, \& Sharma, 1985; Brickley et al., 1997). Thus, the debate on CEO duality leadership is characterized by considerable divergence of opinion and little consensus (e.g., Dalton et al., 1998; Brickley et al., 1997; Finkelstein \& D'Aveni, 1994).

Table 1

Prior Empirical Research on CEO Duality-Firm Performance Relationship

\begin{tabular}{|c|c|c|c|}
\hline $\begin{array}{l}\text { Empirical } \\
\text { Findings }\end{array}$ & Author(s) & Sample and Methods & Performance Measures \\
\hline \multirow[t]{3}{*}{$\begin{array}{l}\text { Positive Impact } \\
\text { on Performance }\end{array}$} & $\begin{array}{l}\text { Donaldson \& Davis } \\
\text { (1991) }\end{array}$ & $\begin{array}{l}\text { 321 U.S. corporations from Standard } \\
\text { \& Poor's register, } \\
\text { 1988, survey method }\end{array}$ & $\begin{array}{l}\text { ROE, Stockholder return (capital gains } \\
\text { from appreciation of stock price) }\end{array}$ \\
\hline & Boyd (1995) & $\begin{array}{l}192 \text { firms from } 12 \text { industries, } 1980, \\
\text { data from Moody's manual and } \\
\text { Compact Disclosure }\end{array}$ & $\begin{array}{l}\text { Sales growth, ROI, } \\
\text { Industry market share } \\
* \text { Contingent on munificent and } \\
\text { complex environments }\end{array}$ \\
\hline & $\begin{array}{l}\text { Brickley, Coles, \& } \\
\text { Jarrell (1997) }\end{array}$ & 661 firms from Forbes survey, 1988 & ROA, Stockholder return \\
\hline \multirow{3}{*}{$\begin{array}{l}\text { Negative } \\
\text { Impact on } \\
\text { Performance }\end{array}$} & $\begin{array}{l}\text { Rechner \& Dalton } \\
(1991)\end{array}$ & $\begin{array}{l}141 \text { firms from Fortune 500, } \\
\text { Longitudinal study (1978-1983) }\end{array}$ & ROE, ROI, Profit \\
\hline & Pi \& Timme (1993) & $\begin{array}{l}112 \text { banks, Longitudinal study (1987- } \\
1990)\end{array}$ & ROA, Cost efficiency \\
\hline & Daily \& Dalton (1994) & $\begin{array}{l}\text { Paired sample of } 57 \text { firms from the } \\
\text { period of } 1972-1982\end{array}$ & Bankruptcy vs. Non-bankruptcy \\
\hline \multirow[t]{6}{*}{$\begin{array}{l}\text { No Systematic } \\
\text { Relationship }\end{array}$} & $\begin{array}{l}\text { Rechner \& Dalton } \\
(1989)\end{array}$ & $\begin{array}{l}141 \text { firms from Fortune 500, } \\
\text { Longitudinal study }(1978-1983)\end{array}$ & Stockholder return \\
\hline & Berg \& Smith (1978) & $\begin{array}{l}200 \text { firms from Fortune } 200 \\
\text { companies in } 1976\end{array}$ & ROE, ROI, Stockholder return \\
\hline & $\begin{array}{l}\text { Chaganti, Mahajan, \& } \\
\text { Sharma (1985) }\end{array}$ & $\begin{array}{l}\text { Paired sample of } 21 \text { firms, } \\
\text { retailing industry, Longitudinal study } \\
(1971-1976)\end{array}$ & Bankruptcy vs. Non-bankruptcy \\
\hline & Boyd (1995) & $\begin{array}{l}192 \text { firms from } 12 \text { industries, } \\
\text { 1980, data from Moody's manual and } \\
\text { Compact Disclosure }\end{array}$ & $\begin{array}{l}\text { Sales growth, ROI, } \\
\text { Industry market share } \\
* \text { Contingent on dynamic environments }\end{array}$ \\
\hline & $\begin{array}{l}\text { Baliga, Moyer, \& Rao } \\
\text { (1996) }\end{array}$ & $\begin{array}{l}111 \text { firms from Fortune 500, } 1990, \\
\text { Announcement effects of changes in } \\
\text { CEO duality }\end{array}$ & $\begin{array}{l}\text { ROE, ROA, Operating cash flow/total } \\
\text { assets, Stockholder return (MVA) }\end{array}$ \\
\hline & Daily (1995) & $\begin{array}{l}72 \text { firms filling for bankruptcy } \\
\text { protection during the period of } 1980- \\
1986\end{array}$ & Bankruptcy Reorganization \\
\hline
\end{tabular}

Unfortunately, to date, extant literature has paid little attention to investigating the implications of CEO duality leadership on strategic management such as firm risk-taking behavior. To our best knowledge of the literature focusing on CEO duality, no research has shed light on managerial risk-taking propensity which is an important aspect in strategic management. Moreover, little is known on whether the presence of duality at the corporate top contributes to agent opportunism or promotes stewardship pro-organizational behavior in firm strategic management practices. If managerial utility functions are well-served by duality leadership, we can reasonably expect organizations led by CEO duality to exhibit lower risk preferences than those where there is a separation of the two pivotal positions at the corporate top. Thus, we empirically investigate how CEO duality structure affects firm risk-taking propensity in strategic management using a data sample of 290 companies listed in the Fortune 1000. For a more comprehensive understanding about the structural context of CEO duality leadership, 
we also examine the role of control mechanisms (board independence, CEO and board equity ownership, and ownership concentration) in modifying managerial risk-taking behavior in CEO duality leadership.

\section{THEORY AND RESEARCH HYPOTHESES}

\section{CEO Duality Leadership And Managerial Risk-Taking Behavior}

Risk is one of the key components in managerial decisions and has featured prominently in strategic management research (Ruefli, Collins, \& Lacugna, 1999). Numerous researchers in the past have studied the determinants of risk behavior focusing on the dispositional characteristics of decision makers (e.g., Hambrick, Cho, $\&$ Chen, 1996) and the organizational and industrial contexts affecting managerial risk-taking behavior (e.g., Palmer \& Wiseman, 1999; Bromiley, 1991; Das \& Teng, 2001). One other stream of research on risk uses agency theory as its theoretical framework. The underlying assumption is that principals are risk neutral while mangers (agents) tend to be risk averse. ${ }^{1}$ Prior risk literature based on agency theory suggests that the risk orientations of agents and principals are different (e.g., Hoskisson, Hitt, \& Hill, 1993). Management scholars supporting agency theory suggest that managers are risk-averse and shareholders are risk-neutral (Beatty \& Zajac, 1994). In other words, if there is a good business opportunity potentially involving risk, principals expect managers to take the business opportunity and maximize their investment returns, while managers are hesitant to take the risky options because their returns and rewards (e.g., salary) from the risk-taking are limited. Moreover, managers are concerned more about downward risk such as dramatic decreases in firm performance and even firm bankruptcy, because managers' human capital is highly tied to the firm. In other words, they are more concerned about their employment risk and firm survival than profit maximization of shareholders (Baysinger \& Hoskisson, 1990). Therefore, managers will place survival and stable income flow at a higher priority than firm profit maximization (Baysinger \& Hoskisson, 1989). On the other hand in the agent-shareholder relationship, shareholders or principals have risk neutral position regarding the firm's strategic choices, because investors can easily diversify their investment risk through the stock market, efficiently reducing their risk level (Beatty \& Zajac, 1994). Thus, in order to align these differences, agency costs will have to be incurred. (e.g., Baysinger, Kosnik, \& Turk, 1991; Beatty \& Zajac, 1994).

Previous researchers in this research stream have provided empirical evidence supporting this argument of risk differentials between managers and investors in strategic management. Baysinger and Hoskisson (1990) found that non-owner managerial behavior leads to increased levels of corporate diversification, particularly into unrelated industries to reduce managerial risk. Research focusing on firm R\&D investment supports the argument that managers are more reluctant to $R \& D$ spending, because returns from $R \& D$ projects often requires considerable time and it involves uncertainty and risk (Hansen \& Hill, 1991; Laverty, 1993). The R\&D project is typically a long-term investment that involves substantial risk often with high failure rates (Ettlie, 1998). Managers are more likely to reduce R\&D investment, particularly if it involves high risk and long-term periods in realizing the profits (Baysinger et al., 1991; Zahra, 1995; Kochhar \& David, 1996). Proponents of agency theory also support this argument that managers or agents are more likely to under invest in R\&D projects, because their objectives and interests are in securing their personal wealth and employment security (Baysinger et al., 1991; Alchian \& Demsetz, 1972). Thus, we argue that power concentration on dual CEO and subsequent ineffective controlling functions from the board will reduce firm risk level, serving managerial risk preference. Their opportunistic risk aversion, combined with ineffective control from the board, may lead to decreased firm risk often to the detriment of shareholder's profit maximization. Thus:

Hypothesis 1: CEO duality will be negatively associated with firm risk-taking propensity.

\footnotetext{
${ }^{1}$ Wiseman and Gomez-Mejia (1998: 136) have provided helpful definitions concerning various organizational risk-taking behaviors. Risk aversion refers to the behavior "preferring lower risk options at the expense of returns", risk neutral refers to "preferring options with the highest expected value and in which the risk is fully compensated", and risk seeking refers to "accepting options in which the risk is not fully compensated in hopes of realizing the up-side potential of the option".
} 


\section{Control Mechanisms In CEO Duality Structure}

To address the agency problem associated with different preferences for risk, a major challenge in corporate governance is to design supervisory and incentive mechanisms that can align the risk orientations of agents and principals (Tosi \& Gomez-Mejia, 1989; Wiseman \& Gomez-Mejia, 1998). Previous board researchers have addressed various control mechanisms that affect managerial risk-taking behavior, such as board independence, firm equity ownership and ownership structure (e.g., Baysinger et al., 1991; Stearns \& Mizruchi, 1993; Beatty \& Zajac, 1994). Coles and Hesterly (2000: 200) state that "leadership structure takes place within the context of other governance arrangements." Managerial behavior drawn from one particular governance structure (e.g., CEO duality) would be an outcome of various interactions with other control mechanisms and organizational structure. Thus, we focus on governance control mechanisms that potentially interact with CEO duality leadership affecting managerial risk-taking behavior.

\section{CEO Equity Ownership}

Agency theorists suggest managerial equity ownership as a way to mitigate agency problems and align the managers' interests with those of the shareholders (Jensen \& Meckling, 1976). Agency theorists argue that CEO ownership would help to achieve alignment between the interests of the CEO (as an agent) and principals, because the value of CEO's equity holdings varies directly with the firm value and performance (Jensen \& Meckling, 1976). Jensen and Murphy (1990) argue that substantial CEO ownership is one effective method of tying CEO wealth to shareholder wealth. Beatty and Zajac (1994) further argue that equity ownership by CEOs alters their risk preferences and makes it more closely matched to the interests of the principals. For example, Palmer and Wiseman (1999) observed that the stockholdings of top management had a positive impact on managerial risk taking. Bajaj, Chan, and Dasgupta (1998) suggest that in firms with little executive ownership, managers have incentive to underlever the firm to reduce bankruptcy risk. May (1995) also argues that CEOs with substantial shareholdings will exhibit more risk bearing behavior such as choosing riskier investment options. Thus, we predict that dual CEOs will be less risk-averse (i.e., becoming risk-neutral position in pursuing business opportunities) when they have higher equity ownership with the firm because their economic incentives are closely tied to the firm value and performance.

Hypothesis 2: CEO equity ownership will moderate the negative relationship between CEO duality and firm risktaking propensity, with the relationship being weaker when the CEO has higher levels of equity ownership with the firm.

\section{Board Independence}

Monitoring mechanisms often involve the selection of socio-politically independent boards. Agency theory emphasizes the importance of board independence as a prerequisite for its effectiveness as a body exercising controlling and monitoring functions over management (e.g., Eisenhardt, 1989; Fama \& Jensen, 1983). Agency theorists argue that without effective control systems, managers are likely to pursue opportunistic behavior to maximize their own utility rather than shareholder wealth maximization. For example, dominance of inside executives on the board may suggest that the board is less effective in controlling opportunistic CEO because they are hierarchically under influence of the CEO. Further, when the CEO is also the chairperson of the board, board's capacity to monitor the CEO is even further diminished. It has been argued that boards adopting CEO duality leadership are less likely to dissent and critically question boardroom strategic decisions (Mallette \& Fowler, 1992). Thus, we argue that the concentration of power in the hands of the CEO and the resultant potential on the CEO's part to act opportunistically can be, at least, mitigated by the presence of directors who are independent of the CEO. Based on this reasoning, we propose board independence as a moderator of the relationship between CEO duality and firm risk-taking propensity. A board dominated by independent directors from the dual CEO will be more effective in controlling opportunistic managerial risk-taking behavior.

Hypothesis 3: Board independence will moderate the negative relationship between CEO duality and firm risktaking propensity, with the relationship being weaker when the board is independent from the CEO. 


\section{Board Equity Ownership}

The incentive for monitoring is stronger when directors also have ownership equity in the firm (Eisenhardt, 1989). Equity ownership by directors makes their interests more aligned with those of the shareholders and causes them to be more effective in their monitoring function. Finkelstein and D'Aveni (1994) suggest that vigilant boards are composed of independent outside directors with high equity ownership in the firm. Westphal and Zajac (1995) argue that director's equity ownership provides additional incentive to challenge CEOs' opportunistic initiatives. Several researchers in the past have empirically examined the effects of board equity ownership on the effectiveness of board's monitoring and controlling functions (e.g., Finkelstein, 1992; Westphal \& Zajac, 1995). For example, Li and Simerly (1998) found that equity ownership by directors encourages them to pursue more long-term performance, which serves principal's utility functions. Thus, directors' economic motives in controlling management opportunism are reflected in the hypothesis arguing that equity ownership by the directors encourage them to be more active in monitoring and controlling management, constraining managerial risk-averse behavior in strategic management.

Hypothesis 4: Board equity ownership will moderate the negative relationship between CEO duality and firm risktaking propensity, with the relationship being weaker when the board has higher levels of equity ownership with the firm.

\section{Ownership Concentration}

Board researchers have suggested that ownership structure has substantial impact on managerial behavior (e.g., Wright, Ferris, Sarin, \& Awasthi, 1996; Hoskisson, Hitt, Johnson, \& Grossman, 2002). Ownership is a source of power in governance control. It also provides economic incentive to more effectively monitor and control the managerial strategic initiatives. In this regard, it has been argued that if the firm ownership structure is highly dispersed, then monitoring and controlling functions would be less effective (Hoskisson et al., 2002). An empirical research provides evidence that firms with highly dispersed ownership may pursue excessive corporate diversification because monitoring cannot be effectively pursued by dispersed owners (Hoskisson \& Turk, 1990). Other researchers in the past found that there is a negative relationship between ownership concentration and firm's diversification level, suggesting that ownership is related to active monitoring of agent managers (Lloyd, Hand, \& Modani, 1987). Regarding the effect of institutional owners on the board, representation of large block holders on the board has a positive impact on increasing the firm's risk-taking propensity (Pennings, 1980; Stearns \& Mizruchi, 1993). These previous studies suggest that concentrated ownership increases board's power and provides an incentive for a more effective monitoring and controlling on managerial opportunistic initiatives. Thus we predict:

Hypothesis 5: Ownership concentration will moderate the negative relationship between CEO duality and firm risktaking propensity, with the relationship being weaker when the distribution of ownership in the firm is concentrated.

\section{METHODOLOGY}

\section{Sample}

To test the hypotheses, a data setting of Fortune 1000 firms for the year of 2002 was elected. Since one of the study objectives is to reduce theoretical and empirical ambiguity surrounding CEO duality leadership, generalizability of study results would be an important criterion in methodological aspects (i.e., research results should not be from a specific industry condition and governance structure). In this regard, Fortune 1000 firms provide an appropriate setting for increasing the potential generalizability of results based on the sample, since these firms encompass a variety of business strategies, industries, and governance structures. Given the fact that about 75 to 80 percent of large U.S. firms adopt CEO duality leadership (Brickley et al., 1997), a stratified random sampling was used based on the criterion of CEO duality versus non-CEO duality. Thus, in total, 290 firms were randomly selected consisting of $145 \mathrm{CEO}$ duality and 145 non-CEO duality firms. 


\section{Measures}

CEO Duality

CEO duality is coded as 1 if an individual simultaneously serves as both CEO and chairperson of the board and ' 0 ' otherwise. A recent study conducted by Coles and Hesterly (2000) elaborated CEO duality measure in which dual CEOs who have previous affiliations with the firm are categorized as non-CEO duality firm. Although their measure enhances conceptual precision in measuring the concept of CEO duality, we believe that it can involve subjectivity in categorization. We argue that in real selection practice, there will few new CEOs and board chairpersons who are totally independent and objective to the organization because they are directly and indirectly tied to the company through various social networks. Thus, we relied on formal hierarchical structure. By employing this measure, we more focus on the structural impact of CEO duality on managerial behavior regarding firm risk. The data were obtained from the firm's proxy statements.

\section{Firm Risk}

One of the major issues in research on firm risk-taking has been the measurement of firm risk (Fiegenbaum \& Thomas, 1986; Wiseman \& Gomez-Mejia, 1998). Baird and Thomas (1990) examined how risk has been conceptualized in different disciplines of management, finance, marketing and psychology, and found various conceptualizations of risk. They observed that researchers in the area of strategic management typically defined risk as unpredictability of business outcome variables (e.g., variability of accounting or stock returns). Miller and Bromiley (1990) suggest that measures employed in the study of firm risk may reflect different dimensions of risk. They identified three dimensions based on a factor analysis of nine measures of risk: income stream risk (variation in returns over time), strategic risk (primarily debt ratio), and stock returns risk (beta). A more recent research reviewing risk studies published from 1980 through 1995 showed that beta from the Capital Asset Pricing Model (CAPM) and income variance are the two most widely used measures of firm risk in strategic management literature (Ruefli et al., 1999). In this study we employed income stream risk for the measure of firm risk because managerial risk-taking behavior can be best reflected in firm's income stream variance. An empirical study testing the association between managerial risk taking and organizational risk also provide a direct positive relationship between the two (Palmer \& Wiseman, 1999). We measured the income stream risk as the standard deviation of ROA (e.g., Bettis \& Mahajan, 1985; Cool, Dierickx, \& Jemison, 1989). Financial data were available from Compustat.

\section{Board Composition}

Previous board researchers have suggested various conceptualizations and operationalizations of board independence, including inside director proportion (e.g., Cochran, Wood, \& Jones, 1985), outside director proportion (e.g., Dalton \& Kesner, 1987), affiliated director proportion (Daily \& Dalton, 1994), and independent/ interdependent distinction (e.g., Boeker, 1992; Daily, 1995; Wade, O’Reilly, \& Chandratat, 1990). Following Boeker (1992), this study employs the independence-interdependence measure because it provides a fair reflection of the socio-political aspects in CEO-board relations. This measure defines independent directors as outside board members who are appointed prior to the current CEO. In this measure, directors who were appointed to the board prior to the current CEO are regarded as relatively more independent from the CEO than the directors who were appointed during the current CEO's tenure. CEO and director equity ownership was measured as the percentage of total common equity owned by CEO and the directors respectively (Finkelstein, 1992). The data for board independence and equity ownership by directors and CEO were available on corporate proxy statements (e.g., 10-K and 14 Def.) filed with the Securities Exchange Commission (SEC).

\section{Ownership Concentration}

Ownership concentration was measured as the concentration of institutional investors' ownership (Hartzell \& Starks, 2003). We employed the Herfindahl Index for calculating the institutional investor ownership concentration ratio accounted for by the top five institutional investors in a firm. Larger values in the Herfindahl 
index indicate a more concentrated ownership structure in a firm. Data on institutional equity holdings were available from the Mergent database.

\section{Control Variables}

This research also controlled for several factors that have been shown in past research to be associated with firm risk. Zahra and Pearce (1989) suggest that greater scale of the firm may increase the amount of uncertainty and complexity in the firm's operation. Thus, previous empirical studies have suggested a positive relationship between firm size and firm risk (Graves, 1988; Hansen \& Hill, 1991). We, therefore, controlled for firm size which was measured as the firm revenue for the three year of 2002. We also controlled for past firm performance. Prospect theory (e.g., Kahneman \& Tversky, 1979) suggests that a firm with performance above industry average (i.e., reference point) is likely to be risk-averse and would assume less risky options. Empirical findings also support the argument that low performance leads to greater risk propensity and high performers are often less inclined to take risks (e.g., Wiseman \& Bromiley, 1996). Past firm performance is calculated by averaging the return on assets (ROA) for the three-year period from 1999 to 2001. This study also controlled for board size. From a group dynamics perspective, larger board may suffer from diffusion of responsibility (Janis, 1989) and decreased levels of motivation in monitoring and controlling management (Jewell \& Reitz, 1981). Board size is measured as the number of directors on the board.

In addition, given that past research has associated industry conditions with firm risk (e.g., Reed \& Luffman, 1986; Fiegenbaum \& Thomas, 1986), we controlled for industry profitability. Industry profitability is measured as average percentage change in profit for all firms included in the sample for the period from 1999 to 2001. Calculation of average industry profitability is based on the two-digit SIC code. Financial data were obtained from the S\&P Compustat database. We also included a dummy variable of manufacturing industry (manufacturing industry $=1$ and ' 0 ' otherwise) to control for industry types. Firms at SIC code 2000 and 3000 levels are classified as manufacturing firms. In the past, strategy researchers focusing on agency theory have argued that opportunistic managers may diversify their business domains into unrelated industries to stabilize corporate income flows and to further reduce managerial risk (Amihud \& Lev, 1981; Baysinger \& Hoskisson, 1990). That is, firm risk reduction is obtained through combining business lines with less correlated business cycles and financial flows. Thus, this study controlled for corporation's level of unrelated diversification. We used Jacquemin and Berry's (1979) entropy measure. The level of unrelated diversification is measured by the degree to which a firm's sales are allocated across unrelated (different two-digit SIC codes) industry segments. The sales data for the business lines were obtained from the S\&P Compustat database. We also controlled for CEO tenure. Previous researchers finds that CEOs tend to make fewer strategic changes as their tenure increases (Grimm \& Smith, 1991; Hambrick et al., 1996) leading to more risk-averse behavior in firm strategic management. We measured the CEO tenure as the number of months the CEO has served in the firm (Wiersema \& Bantel, 1992).

\section{Statistical Analysis}

We conducted moderated hierarchical regression analyses to test main and interactive effects of CEO duality on firm risk-taking propensity (Aiken \& West, 1991; Cohen \& Cohen, 1983). Following the procedure provided by Sharma, Durand, and Gur-Arie (1981), seven control variables included in this study were entered in the first hierarchical step. After entering the control variables, we entered CEO duality in the second step to examine the relative direct contribution of CEO duality. In the third step, moderating variables of CEO equity ownership, board independence, board equity ownership, and ownership concentration then entered. Finally, the two-way interaction terms representing moderators were entered. The significance of coefficients and incremental variances explained by the variables were examined for testing the significance.

\section{RESULTS}

The means, standard deviations, and correlations for the sample are presented in Table 2. The sample firms encompass a variety of industries and 195 firms out of 290 firms were in manufacturing industry. Sample firms in average have 10.9 directors in their board. Descriptive statistics show that 47.3 percent of directors in the sample 
firms were independent in terms of the measure used (s.d.=.29). There was no significant difference between duality and non-duality firms in terms of board independence. CEOs on average have 1.5 percent of the equity ownership and directors (excluding the ownership by CEO) held about 6.8 percent ownership, but there was large variation in the ownership data (s.d. $=.04$; s.d. $=.20$ respectively). In the simple T-test, boards in non-duality firms had significantly higher ownership equity than the boards in duality firms at the .05 level. CEOs in the CEO duality firms have significantly longer tenure than the CEOs in nonduality firm $(p<.05)$. However, there was no significant difference in CEO ownership between duality versus non-duality firms. As the ownership data was positively skewed, we applied a natural logarithm on these variables of CEO and board equity ownership. We also applied a $\log$ transformation for the variable of firm size and ownership concentration because of the positive skewness in these data. In regards to firm diversification, CEO duality firms show significantly higher levels of unrelated diversification than non-duality firms $(p<.05)$. In the statistical tests involving interaction terms (regression model 4 in Table 3), there was concern for multicollinearity when the interaction term between CEO duality and board independence was included in the model, thus scale transformation (mean deviates) was applied on the variable of board independence when we test the moderating effects (Variance Inflation Factor was less than 2.31 after the rescaling). Aiken and West (1991: 29) suggest that rescaling methods do not affect the significance of coefficients for the highest order term (interaction term in the model 4) in regression analysis.

Table 3 reports the results of the hierarchical regression analysis. Hypothesis 1 predicts that CEO duality will be negatively associated with firm risk level measured as income stream risk. Test results of hypothesis 1 provide empirical evidence that firms adopting CEO duality leadership show significantly lower levels of firm risk $(-1.11 ; p<.05$, model 2$)$. The result is consistent with the agency theory perspective that power concentration on dual $\mathrm{CEO}$ and resultant weak board leads to lower risk-taking propensity in the firm.

Hypotheses 2 through 5 focus on moderating roles of governance mechanisms in the relationship between CEO duality and firm risk-taking behavior. Hypothesis 2 suggests a moderating effect of CEO equity ownership in the relationship between CEO duality and firm risk-taking behavior, arguing that higher CEO equity ownership will positively moderate the negative relationship between CEO duality and firm risk. There was no significant moderating effect for the CEO equity ownership in controlling managerial risk-taking behavior. Hypothesis 3 predicted that board independence would moderate the relationship between CEO duality and firm risk-taking behavior. That is, when the board is characterized by higher levels of independence, this will reduce managerial opportunism regarding firm risk. The results show no evidence of significant moderating effect of board independence on the relationship between CEO duality and firm risk, providing no evidence for agency argument regarding the role of board independence. Hypothesis 4 predicted a moderating effect of board equity ownership in the relationship between CEO duality and firm risk suggesting that when the board has lower levels of equity ownership with the firm, CEO duality leadership will be more negatively related to firm risk-taking behavior. There was no significant moderating effect of board equity ownership. Thus, hypothesis 4 developed based on agency perspective regarding agent equity ownership was also not supported.

Hypotheses 5 suggest a moderating effect of ownership concentration in the relationship between CEO duality and firm risk-taking behavior. We predicted that as the distribution of ownership in the firm becomes more concentrated, monitoring and controlling functions over the management will be more actively conducted, thus reducing managerial risk-averse behavior in strategic management. The test results of hypothesis 5 provide empirical evidence supporting the argument. There was a significant positive interaction effect between CEO duality and ownership concentration (45.14; $p<.05$; model 4; VIF<2.0). CEO duality leadership under the control of large institutional stock holders on the board shows higher levels of firm risk-taking. The results suggest that large block holders on the board have substantial role in modifying managerial risk-taking behavior. 
Table 2

Pearson Correlation Coefficient Matrix ${ }^{2}$

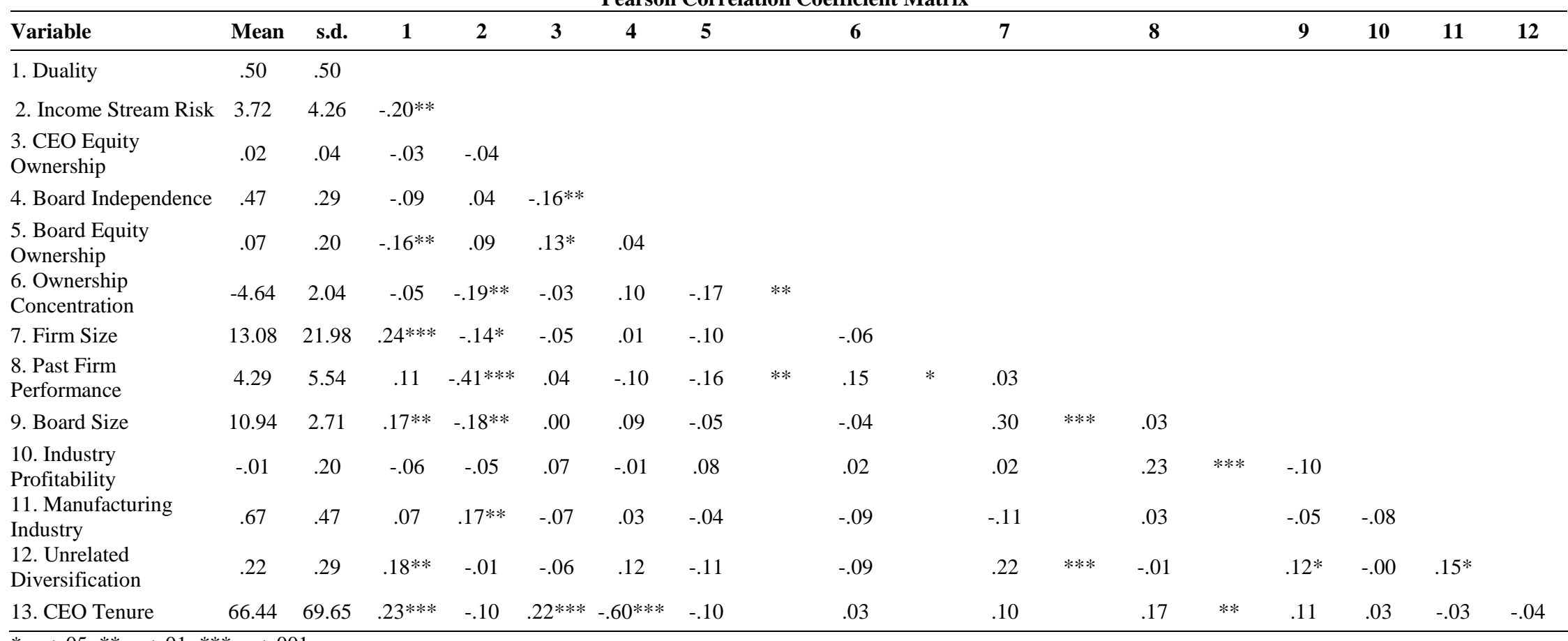

$* p<.05 ; * * p<.01 ; * * * p<.001$ 
Table 3

Regression Models: CEO Duality and Firm Risk ${ }^{3}$

\begin{tabular}{|c|c|c|c|c|c|c|c|c|}
\hline Variable & Mode & & Model & & Mode & & Model & \\
\hline (Constant) & $\begin{array}{l}9.98 \\
(1.98)\end{array}$ & $* * *$ & $\begin{array}{l}8.36 \\
(2.10)\end{array}$ & $* * *$ & $\begin{array}{l}7.01 \\
(2.21)\end{array}$ & $* *$ & $\begin{array}{l}6.56 \\
(2.28)\end{array}$ & $* *$ \\
\hline Firm Size & $\begin{array}{l}-.47 \\
(.24)\end{array}$ & $*$ & $\begin{array}{l}-.24 \\
(.26)\end{array}$ & & $\begin{array}{l}-.33 \\
(.27)\end{array}$ & & $\begin{array}{l}-.31 \\
(.27)\end{array}$ & \\
\hline Past Firm Performance & $\begin{array}{l}-.31 \\
(.04)\end{array}$ & $* * *$ & $\begin{array}{l}-.30 \\
(.04)\end{array}$ & $* * *$ & $\begin{array}{l}-.29 \\
(.04)\end{array}$ & $* * *$ & $\begin{array}{l}-.29 \\
(.04)\end{array}$ & $* * *$ \\
\hline Board Size & $\begin{array}{l}-.16 \\
(.09)\end{array}$ & $\dagger$ & $\begin{array}{l}-.17 \\
(.09)\end{array}$ & $\dagger$ & $\begin{array}{l}-.20 \\
(.09)\end{array}$ & $*$ & $\begin{array}{l}-.18 \\
(.10)\end{array}$ & $\dagger$ \\
\hline Industry Profitability & $\begin{array}{l}1.73 \\
(1.19)\end{array}$ & & $\begin{array}{l}1.65 \\
(1.18)\end{array}$ & & $\begin{array}{l}1.50 \\
(1.20)\end{array}$ & & $\begin{array}{l}1.30 \\
(1.21)\end{array}$ & \\
\hline Manufacturing Industry & $\begin{array}{l}1.32 \\
(.50)\end{array}$ & $* *$ & $\begin{array}{l}1.49 \\
(.50)\end{array}$ & $* *$ & $\begin{array}{l}1.31 \\
(.52)\end{array}$ & $*$ & $\begin{array}{l}1.33 \\
(.52)\end{array}$ & $* *$ \\
\hline Unrelated Diversification & $\begin{array}{l}.02 \\
(.81)\end{array}$ & & $\begin{array}{l}.13 \\
(.80)\end{array}$ & & $\begin{array}{l}.07 \\
(.80)\end{array}$ & & $\begin{array}{l}.06 \\
(.81)\end{array}$ & \\
\hline CEO Tenure & $\begin{array}{l}.00 \\
(.00)\end{array}$ & & $\begin{array}{l}.00 \\
(.00)\end{array}$ & & $\begin{array}{l}.00 \\
(.00)\end{array}$ & & $\begin{array}{l}.00 \\
(.00)\end{array}$ & \\
\hline CEO Duality & & & $\begin{array}{l}-1.11 \\
(.52)\end{array}$ & $*$ & $\begin{array}{l}-1.08 \\
(.54)\end{array}$ & $*$ & $\begin{array}{l}-1.91 \\
(.74)\end{array}$ & $*$ \\
\hline CEO Equity Ownership & & & & & $\begin{array}{l}-.24 \\
(.18)\end{array}$ & & $\begin{array}{l}-.24 \\
(.19)\end{array}$ & \\
\hline Board Independence & & & & & $\begin{array}{l}.19 \\
(1.00)\end{array}$ & & $\begin{array}{l}-.60 \\
(1.22)\end{array}$ & \\
\hline Board Equity Ownership & & & & & $\begin{array}{l}.05 \\
(.12)\end{array}$ & & $\begin{array}{l}.05 \\
(.14)\end{array}$ & \\
\hline Ownership Concentration & & & & & $\begin{array}{l}-.25 \\
(.11)\end{array}$ & $*$ & $\begin{array}{l}-.35 \\
(.12)\end{array}$ & $* *$ \\
\hline CEO Duality $\times$ CEO Equity Ownership & & & & & & & $\begin{array}{l}2.13 \\
(9.12)\end{array}$ & \\
\hline CEO Duality $\times$ Board Independence & & & & & & & $\begin{array}{l}1.63 \\
(1.61)\end{array}$ & \\
\hline CEO Duality $\times$ Board Equity Ownership & & & & & & & $\begin{array}{l}-1.07 \\
(2.60)\end{array}$ & \\
\hline CEO Duality $\times$ Ownership Concentration & & & & & & & $\begin{array}{l}45.14 \\
(22.82)\end{array}$ & $*$ \\
\hline R-Squared & .23 & & .25 & & .26 & & .28 & \\
\hline Change in R-Squared & .23 & & .01 & & .02 & & .01 & \\
\hline F-test & 11.87 & $* * *$ & 11.11 & $* * *$ & 8.04 & $* * *$ & 6.37 & $* * *$ \\
\hline F-test for change in F-value & 11.87 & $* * *$ & 4.64 & $*$ & 1.68 & & 1.29 & \\
\hline
\end{tabular}

$\dagger \leq .10 ; * p \leq .05 ; * * p \leq .01 ; * * * p \leq .001$

The control variables of firm size, past firm performance, board size, and manufacturing industry included in this study had significant effects on firm risk. Increases in firm size and firm performance led to lower levels of firm risk $(p<.05$ and $p<.01$, respectively). Board size is negatively related to firm risk $(p<.10)$. Firms in

\footnotetext{
${ }^{3}$ Standard errors are shown in parentheses.
} 
manufacturing industries had higher levels of income stream variance $(p<.01)$. Diversification into unrelated industries had no significant impact on reducing firm risk.

\section{DISCUSSION}

Given the theoretical and empirical ambiguity surrounding CEO duality leadership, the results of this study examining the intermediate outcomes of firm risk-taking propensity provides clearer implications about the desirability of CEO duality leadership often adopted by large U.S. corporations. We expect the study findings to have important implications for both governance researchers and practitioners. From the viewpoint of scholars interested in corporate governance the findings of this study should provide insights on how the governance structure (CEO duality) impacts the firm strategic behavior, specifically with regard to the firm risk. From a managerial standpoint, the results should also provide guidelines on the desirability of duality and also on whether governance mechanisms help mitigates the potential agency problems associated with CEO duality leadership.

We provide empirical evidence regarding how combined leadership structure affects managerial behavior regarding firm risk which is an important element in corporate strategic management and shareholder's investment utility maximization. The empirical examination of 290 large U.S. corporations provides evidence supporting agency perspective that combined leadership structure facilitates managerial opportunism that firms with CEO duality structure had significantly lower levels of firm risk-taking propensity, which serves managerial risk preferences. The results imply that CEO duality structure intensifies the issue of power concentration on CEO and weakens the board's effectiveness in monitoring and controlling management. Thus, the findings of this study highlight the issue of power concentration on CEO and subsequent impacts on managerial firm behavior in strategic management. The results of this study support the argument that power concentration in joint leadership structure facilitates managerial opportunism in corporate strategic management. That is, CEO duality structure provides less effective checks and balance mechanism in controlling managerial opportunism.

We also argue that the findings in this study are consistent with recent theoretical and empirical prescriptions on CEO duality leadership. For example, Pollock, Fischer, and Wade (2002) observed that CEO duality resulted in increased likelihood of executive options being repriced - an action generally found objectionable by shareholders. A more recent study found that there was more occurrence of earnings management (i.e., manager's impression management through use of flexible accounting principles to distort actual earnings) when the firm had CEO duality leadership, suggesting ineffective monitoring functions in the firm (Davidson, Jiraporn, Kim, \& Nemec, 2004). A study examining the impact of CEO duality on the reorganization process of firms in bankruptcy filing found that dual CEOs delay the approval of reorganization plans to increase their power and facilitate CEO entrenchment in the firm (Brockmann et al., 2004). These empirical findings together with the results of this research suggest various adverse effects associated with CEO duality leadership. As previous board researchers have emphasized the balance of power among governance entities (i.e., relative power of board to incumbent CEO and vice versa) (e.g., Finkelstein \& D'Aveni, 1994; Shen \& Cannella, 2002; Westphal \& Zajac, 1995), we argue that power concentration on dual CEO increases the chance of managerial opportunism in firm management.

For richer insights about the relationship between CEO duality structure and firm risk-taking behavior, several elements were incorporated into the empirical model that have been highly researched in previous studies in corporate governance. These are the governance mechanisms of CEO and board equity ownership, board independence, and ownership concentration. We included these moderating variables to reflect both socio-political and economic aspects in agent-principal relationship. The results of this study suggest that these control mechanisms have little impact in controlling managerial behavior in CEO duality firms, providing little empirical evidence regarding the role of these governance mechanisms. However, we find a significant impact of ownership structure on controlling managerial behavior in CEO duality leadership. We found empirical evidence that concentration of stock ownership in the firm does have substantial influence on managerial behavior. The results provide evidence that ownership concentration interacts with CEO duality leadership and modifies managerial behavior regarding firm risk, resulting in increases in firm risk. That is, dual CEOs perceive powerful control from large block holders in the firm. Dual CEOs perceive voting power of block holders that has substantial impact on their employment security and their leadership. This suggests that the issue of power concentration in CEO duality leadership is mitigated and/or balanced by powerful block holders in the firm. Given the findings of this research, investors and stakeholders might be well advised to consider the importance of power balance in CEO-board relations for designing effective control mechanisms in corporate governance. 
Interestingly, ownership concentration itself had a negative effect on firm risk, $(-.25 ; p<.05$; Table 3 , model 3). That is, although CEO duality and ownership concentration individually had a negative impact on firm risk, interaction between two entities leads to higher firm risk taking. Our interpretation is that a powerful board (i.e., large block holders on the board) induces defensive behavior from the CEO and executives resulting in lower firm risk levels. However, when dual CEO and block holders on the board interact at the corporate top, they pursue riskier business opportunities and options for higher investment returns and firm performance, resulting in higher firm risk levels. The results emphasize the importance of interactions and behavioral dynamics among governance entities in revealing the role of control mechanisms in corporate governance.

As a concluding remark, we also note a caution for readers in interpreting the study results. Given the equivocal empirical evidence regarding the relationship between firm risk and performance (Miller \& Bromiley, 1990), prescriptive argument based on the results of this study is limited to the extent of predicting managerial behavior in strategic management, not to the extent of performance prediction on CEO duality leadership. Secondly, this research focuses on association between CEO duality and firm risk in a research setting that encompasses diverse industry environments and governance structures. Thus, inference about causal relationship between the two is limited. That is, firm risk may influence the adoption of CEO duality leadership rather than the opposite. Future governance researchers may further clarify the causal relationship by employing different research settings such as longitudinal research model.

\section{REFERENCES}

1. Aiken, L.S., \& West, S.G. 1991. Multiple regression: Testing and interpreting interactions. Sage, Newbury Park, CA.

2. Alchian, A.A., \& Demsetz, H. 1972. Production, information costs, and economic organization. American Economic Review, 62: 777-795.

3. Amihud, Y., \& Lev, B. 1981. Risk reduction as a managerial motive for conglomerate mergers. Bell Journal of Economics, 12: 605-617.

4. Baird, I.S., \& Thomas, H. 1990. What is risk anyway? In Bettis, R.A., \& Thomas, H. (eds). Risk, strategy, and management. JAI Press, Greenwich, CT, 21-52.

5. Bajaj, M., Chan, Y.C., \& Dasgupta, S. 1998. The relationship between ownership, financing decisions and firm performance: A signaling model. International Economic Review, 39(3): 723-744.

6. Baliga, B.R., Moyer, R.C., \& Rao, R.S. 1996. CEO duality and firm performance: What's the fuss? Strategic Management Journal, 17: 41-53.

7. Baysinger, B.D., \& Hoskisson, R.E. 1989. Diversification strategy and R\&D intensity in multiproduct firms. Academy of Management Journal, 32(2): 310-332.

8. Baysinger, B., \& Hoskisson, R.E. 1990. The composition of boards of directors and strategic control: Effects on corporate strategy. Academy of Management Review, 15: 72-87.

9. Baysinger, B.D., Kosnik, R.D., \& Turk, T.A. 1991. Effects of board and ownership structure on corporate R\&D strategy. Academy of Management Journal, 34: 205-214.

10. Beatty, R.P., \& Zajac, E.J. 1994. Managerial incentives, monitoring, and risk bearing: A study of executive compensation, ownership and board structure in initial public offerings. Administrative Science Quarterly, 39:313-335.

11. Berg, S.V., \& Smith, S.K. 1978. CEO and board chairman: A quantitative study of dual vs. unitary board leadership. Directors and board, 34-39.

12. Bettis, R.A., \& Mahajan, V. 1985. Risk/return performance of diversified firms. Management Science, 31: 785-799.

13. Boeker, W. 1992. Power and managerial dismissal: Scapegoating at the top. Administrative Science Quarterly, 37: 400-421.

14. Boyd, B.K. 1995. CEO duality and firm performance: A contingency model. Strategic Management Journal, 16: 301-312.

15. Brickley, J.A., Coles, J.L., \& Jarrell, G.A. 1997. Leadership structure: Separating the CEO and chairman of the board. Journal of Corporate Finance, 4: 189-220.

16. Brockmann, E.N., Hoffman, J.J., Dawley, D.D., \& Fornaciari, C.J. 2004. The impact of CEO duality and prestige on a bankrupt organization. Journal of Management Issues, 16(2): 178-196.

17. Bromiley, P. 1991. Testing a casual model of corporate risk taking and performance. Academy of Management Journal, 34(1): 37-59. 
18. Chaganti, R., Mahajan, V., \& Sharma, S. 1985. Corporate board size, composition and corporate failures in the retailing industry. Journal of Management Studies, 22: 400-416.

19. Cochran,P.L., Wood, R.A., \& Jones, T.B. 1985. The composition of board of directors and incidence of golden parachutes. Academy of Management Journal, 28: 664-671.

20. Cohen, J., \& Cohen, P. 1983. Applied multiple regression/correlation analyses for the behavioral sciences $\left(2^{\text {nd }}\right.$ ed.). Hillsdale, NJ: Lawrence Erlbaum.

21. Coles, J.W., \& Hesterly, W.S. 2000. Independence of the chairman and board composition: Firm choices and shareholder value. Journal of Management, 26(2): 195-214.

22. Cool, K., Dierickx, I., \& Jemison, D. 1989. Business strategy, market structure and risk-return relationships: A structural approach. Strategic Management Journal, 10(6): 507-522.

23. Daily, C.M. 1995. The relationship between board composition and leadership structure and bankruptcy reorganization outcomes. Journal of Management, 21: 1041-1056.

24. Daily C.M., \& Dalton D.R. 1994. Bankruptcy and corporate governance: The impact of board composition and structure. Academy of Management Journal, 37(6): 1603-1617.

25. Daily C.M., \& Dalton D.R. 1997. CEO and board chair roles held jointly or separately: Much ado about nothing? Academy of Management executive, 11(3): 11-20.

26. Dalton, D.R., Daily, C.M., Ellstrand, A.E., \& Johnson, J.L. 1998. Meta-analytic reviews of board composition, leadership structure, and financial performance. Strategic Management Journal, 19: 269-290.

27. Dalton, D.R., \& Kesner, I.F. 1987. Composition and CEO duality in boards of directors: An international perspective. Journal of International Business Studies, 18(3): 33-42.

28. Das, T.K., \& Teng, B.S. 2001. Strategic risk behavior and its temporalities: Between risk propensity and decision context. Journal of Management Studies, 38(4): 515-534.

29. Davidson, W.N. III, Jiraporn, P., Kim, Y.S., \& Nemec, C. 2004. Earnings management following dualitycreating successions: Ethnostatistics, impression management, and agency theory. Academy of Management Journal, 47(2): 267-275.

30. Dayton, K.N. 1984. Corporate governance: The other side of the coin. Harvard Business Review, JanuaryFebruary, p.37.

31. Donaldson, L., \& Davis, J. 1991. Stewardship theory or agency theory: CEO governance and shareholder returns. Australian Journal of Management, 16(1): 49-64.

32. Eisenhardt, K.M. 1989. Making fast strategic decisions in high-velocity environments. Academy of Management Journal, 32: 543-577.

33. Ettlie, J.E. 1998. R \& D and global manufacturing performance. Management Science, 44: 1-11.

34. Fama, E.F., \& Jensen, M.C. 1983. Separation of ownership and control. Journal of Law and Economics, 26: 301-325.

35. Fiegenbaum, A., \& Thomas, H. 1986. Dynamic and risk measurement perspectives on Bowman's riskreturn paradox for strategic management: An empirical study. Strategic Management Journal, 7: 395-408.

36. Finkelstein, S. 1992. Power in top management teams: Dimensions, measurement, and vailidation. Academy of Management Journal, 35: 505-538.

37. Finkelstein, S., \& D'Aveni, R.A. 1994. CEO duality as a double-edged sword: How boards of directors balance entrenchment avoidance and unity of command. Academy of Management Journal, 1078-1108.

38. Graves, S.B. 1988. Institutional ownership and corporate R\&D in the computer industry. Academy of Management Journal, 31: 417-427.

39. Grimm, C. M., \& Smith, K. G. 1991. Management and organizational change: A note on the railroad industry. Strategic Management Journal, 12(7): 557-562.

40. Hambrick, D.C., Cho, T.S., \& Chen, M-J. 1996. The influence of top management team heterogeneity on firms' competitive moves'. Administrative Science Quarterly, 41: 659-684.

41. Hansen, G.S., \& Hill, C.W.L. 1991. Are institutional investors myopic? A time-series stud of four technology-driven industries. Strategic Management Journal, 12: 1-16.

42. Harrison, J.R., Torres, D.L., \& Kukalis, S. 1988. The changing of the guard: Turnover and structural change in the top management positions. Administrative Science Quarterly, 33: 211-232.

43. Hartzell, J.C., \& Starks, L.T. 2003. Institutional investors and executive compensation. Journal of Finance, 58: $2351-2374$.

44. Hoskisson, R.E., Hitt, M.A., \& Hill, C.W. 1993. Managerial incentives and investment in R\&D in large multi-product firms. Organization Science, 4: 325-341. 
45. Hoskisson, R.E., Hitt, M.A., Johnson, R.A., \& Grossman, W. 2002. Conflicting Voices: The Effects of Institutional Ownership Heterogeneity and Internal Governance on Corporate Innovation Strategies. Academy of Management journal, 45(4): 697-716.

46. Hoskisson, R.E., \& Turk, T.A. 1990. Corporate restructuring: Governance and control limits of the internal capital market. Academy of Management Review, 15: 459-477.

47. Jacquemin, A.P., \& Berry, C.H. 1979. Entropy measure of diversification and corporate growth. Journal of Industrial Economics. 27(4): 359-369.

48. Janis, I.L. 1989. Crucial decisions: Leadership in policymaking and crisis management. New York: Free Press.

49. Jensen, M.C., \& Meckling, W. H. 1976. Theory of the firm: Managerial behavior, agency costs, and ownership structure. Journal of Financial Economics, 3; 305-350.

50. Jensen, M.C., \& Murphy, K.J. 1990. CEO incentives-it's not how much you pay but how. Harvard Business Review, 68: 138-149.

51. Jewell, L.N. \& Reitz, H.J. 1981. Group effectiveness in organizations. Scott-Foresman, Glenview, IL.

52. Kahneman, D., \& Tversky, D. 1979. Prospect theory: An analysis of decisions under risk. Econometrica, 47: 262-291.

53. Kochhar, R., \& David, P. 1996. Institutional investors and firm innovation: A test of competing hypotheses. Strategic Management Journal, 17(1): 73-84.

54. Laverty, K. J. 1993. How valid are R\&D measures in empirical tests of short-termism? Academy of Management Best Papers Proceedings, 27-31.

55. Li, M., \& Simerly, R.L. 1998. The moderating effect of environmental dynamism on the ownership and performance relationship. Strategic Management Journal, 19: 169-180.

56. Lloyd, W. P., Hand, J.H., \& Modani, N.K. 1987. The Effect of the Degree of Ownership control on Firm Diversification, Market Value, and Merger Activity. Journal of Business Research, 15(4): 303-312.

57. Mallette, P., \& Fowler, K.L. 1992. Effects of board composition and stock ownership on the adoption of poison pills. Academy of Management Journal, 35: 1010-1035.

58. May, D. O. 1995. Do managerial motives influence firm risk reduction strategies? Journal of Finance, 50: 1291-1309.

59. Miller, K., \& Bromiley, P. 1990. Strategic risk and corporate performance: An analysis of alternative risk measures. Academy of Management Journal, 33: 756-779.

60. Palmer, T. B., \& Wiseman, R.M. 1999. Decoupling risk taking from income stream uncertainty: A holistic model of risk. Strategic Management Journal, 20: 1037-1062.

61. Pennings, J. M. 1980. Interlocking directorates. San Francisco: Jossey-Bass.

62. Pi, L., \& Timme, A. 1993. Corporate control and bank efficiency. Journal of Banking and Finance, 17: 515-530.

63. Pollock, T.G., Fischer, H. M., \& Wade, J. B. 2002. The role of power and politics in the repricing of executive options. Academy of Management Journal, 45(6): 1172-1182.

64. Rechner, P. L., \& Dalton, D.R. 1989. The impact of CEO as board chairperson on corporate performance: Evidence vs. rhetoric. Academy of Management Executive, 3: 141-143.

65. Rechner, P. L., \& Dalton, D. R. 1991. CEO duality and organizational performance: A longitudinal analysis. Strategic Management Journal, 12: 155-160.

66. Reed, R., \& Luffman, G. 1986. Diversification: The growing confusion. Strategic Management Journal, 7: 29-36.

67. Ruefli, T. W., Collins, J. M., \& Lacugna, J. R. 1999. Risk measures in strategic management research: Auld lang syne? Strategic Management Journal, 20: 167-194.

68. Sharma, S., Durand, R. M., \& Gur-Arie, O. 1981. Identification and analysis of moderator variables. Journal of Marketing Research, 18(3): 291-300.

69. Shen, W., \& Cannella, A. A. 2002. Revisiting the performance consequences of CEO succession: The impacts of successor type, postsuccession senior executive turnover, and departing CEO tenure. Academy of Management Journal, 45(4): 717-733.

70. Stearns, L. B., \& Mizruchi, M.S. 1993. Board composition and corporate financing: The impact of financial institution representation on borrowing. Academy of management Journal, 36: 603-618.

71. Tosi,H.L., \& Gomez-Mejia, L. 1989. The decoupling of CEO pay and performance: An agency theory perspective. Administrative Science Quarterly, 34: 169-189.

72. Wade, J.B., O'Reilly, C.A., \& Chandratat I. 1990. Golden parachutes: CEOs and the exercise of social influence. Administrative Science Quarterly, 35: 587-603. 
73. Westphal, J. D., \& Zajac, E. J. 1995. Who shall govern? CEO/board power, demographic similarity, and new director selection. Administrative Science Quarterly, 40: 60-83.

74. Westphal, J. D., \& Zajac, E. J. 1998. The symbolic management of stockholders: Corporate governance reforms and shareholder reactions. Administrative Science Quarterly, 43(1): 127-153.

75. Wiersema, M. F., \& Bantel, K. A. 1992. Top management team demography and gorporate strategic change. Academy of Management Journal, 35(1): 91-121.

76. Wiseman, R. M., \& Bromiley, P. 1996. Toward a model of risk in declining organizations: An empirical examination of risk, performance and decline. Organization Science, 7: 524-543.

77. Wiseman, R. M., \& Gomez-Mejia, L. R. 1998. A behavioral agency model of managerial risk taking. Academy of Management Review, 23(1): 133-153.

78. Wright, P., Ferris, S. P., Sarin, A., \& Awasthi, V. 1996. Impact of corporate insider, blockholder, and institutional equity ownership on firm risk taking. Academy of Management Journal, 39: 441-463.

79. Zahra, S. A. 1995. Corporate entrepreneurship and company performance: The case of management leveraged buyouts. Journal of Business Venturing, 10: 225-247.

80. Zahra, S. A., \& Pearce, J. A. 1989. Boards of directors and corporate financial performance: A review and integrative model. Journal of Management, 15: 291-334.

\section{NOTES}




\section{NOTES}

